\title{
GEOCHEMISTRY AND GEOCHRONOLOGY OF THREE PLUTONS FROM CENTRAL URUGUAY: TECTONIC IMPLICATIONS FOR THE TRANSAMAZONIAN OROGENY
}

\author{
FERNANDO PRECIOZZI* \& JAMES H. BOURNE**
}

\begin{abstract}
RESUMO GEOQUÍMICA E OEOCRONOLOGIA DE TRÊS PLÚTONS DO URUGUAI CENTRAL: IMPLICAÇÕES TECTÔNICAS PARA A OROGEENESE TRANSAMAZÔNICA. O Cinturão Arroyo Grande é o menor de três cinturões metamórficos reconhecidos no Uruguai centro-meridional e localiza-se ao longo da margem setentrional do Terreno Piedra Alta. O cinturão hospeda várias intrusões graniticas, três das quais (o Complexo Marinho, 0 Plúton Arroyo Grande e o Granito Sul) são discutidas neste trabalho. As três intrusões variam em composição de homblenditos a leucogranito e foram, por sua vez, intrudidas por inúmeros diques, também de composição variada. O Plúton Arroyo Grande formou-se em um ambiente extensional, enquanto a porção principal do Complexo Marincho teria se formado em um regime tectônico concessional. A unidade principal do Complexo Marinco foi datada a 2.291 $\pm 65 \mathrm{Ma}$, enquanto um membro leucogranítico forneceu $2.067 \pm 24 \mathrm{Ma}$, demonstrando que o Complexo Marincho corresponde a um corpo composto. Um dique leucogranítico, intrusive no Complexo Marincho, definiu uma idade de $1.969 \pm 25 \mathrm{Ma}$. O Granito Sul, leucogranítico, foi datado a 2.180 $\pm 50 \mathrm{Ma}$. O Plúton Arroyo Grande não foi datado. Os dados disponíveis indicam três períodos de colocação de plútons graníticos no Uruguai central e meridional: $\mathbf{1}$. Arqueano, envolvendo metamorfismo de facies xisto verde; 2.2.290 - 2.180 Ma - a época de colocação de granitóides maciços; 3. $2.040-1.894 \mathrm{Ma}$ - colocação de, predominantemente, pequenos diques graníticos.(traduçâo do resumo e legenda das figuras pela Editoria).
\end{abstract}

Palavras-chaves: Granitos ígneos pré-cambrianos, Uruguay, América do Sul, Geoquímica.

\begin{abstract}
The Arroyo Grande Belt is the smallest of the three metamorphic belts recognized in south-central Uruguay and is located along the northern margin of the Piedra Aha Terrane. The belt is host to a number of granitic intrusions, three of which (the Marincho Complex, the Arroyo Grande Pluton and the South Granite) are discussed in this report. The three intrusions vary in composition from homblendite to leucogranite and have themselves been intruded by a number of dykes, also of variable composition. The Arroyo Grande Pluton formed in an extensional environment whereas the main portion of the Marincho Complex formed in a compressional tectonic regime. The main unit of the Marincho Complex has been dated at 2,291 $\pm 65 \mathrm{Ma}$ whereas a leucogranite member of the mass has been dated at 2,067 $\pm 24 \mathrm{Ma}$, thereby demonstrating that the Marincho Complex is a composite mass. A leucogranitic dyke, intrusive into the Marincho Complex, yields an age of 1,969 $\pm 25 \mathrm{Ma}$. The leucogranitic South Granite has been dated at 2,180 $\pm 50 \mathrm{Ma}$. The Arroyo Grande Pluton has not been dated.

The available data indicate three periods of emplacement of granitic plutons in southern and central Uruguay: 1. Archean, involving greenschist facies metamorphism; 2.2,290 Ma - 2,180 Ma.- the time of emplacement of massive granitoids; 3. 2,040 Ma -1,894 Ma. - emplacement of predominantly small granitic dykes.
\end{abstract}

Keywords: Ignous granite Precambrian, Uruguay, South America, Geochemistry, (feitas peto autor)

INTRODUTION From a geotectonic standpoint, Uruguay is a part of the South American Platform which became tectonically stable at the end of the Proterozoic era. This vast area consists of a number of cratonic regions which became stable at the end of the Transamazonian Cycle, separated by a number of fold belts of different ages.

The very few radiometric dates available enable the Precambrian rocks of Uruguay to be subdivided into a number of different age groupings as follows:

$\begin{array}{ll}\text { pre-Transamazonian rocks } & <2,200 \mathrm{Ma} \\ \text { Transamazonian rocks } & 2,200-2,000 \mathrm{Ma} \\ \text { post-Transamazonian rocks } & 1,900-1,700 \mathrm{Ma} \\ \text { pre-Brazilian rocks } & 1,400-1,000 \mathrm{Ma} \\ \text { Brazilian rocks } & 1,000-500 \mathrm{Ma}\end{array}$

The Transamazonian rocks can be subdivided into two main groupings: a. upper amphibolite to granulite facies metamorphic rocks including large areas of granitic rocks and gneissic granites, b. either greenschist facies (Minas de Corrales, Preciozzi et al. 1985, Paso Severino, Cerros de San Juan and Arroyo Grande Fonnations) or amphibolite facies (San José and Montevideo Formations) rocks which are found as thin bands intercalated with the granitic gneiss complex.
The Arroyo Grande Formation (AGF) (Ferrando \& Fernandez 1971, Fernandez \& Preciozzi 1974, Preciozzi et al. 1979) is located along the northwestern margin of the Uruguay Crystalline Terrane (Fig. 1), which forms the basement to the Rio de la Plata Basin. The AGF has been intruded by a number of bodies of granitic rocks, three of which are the Marincho Complex (MC), the South Granite (SG) and the Arroyo Grande Pluton (AGP). The purpose of this article is to present petrographic, geochronologic and whole rock geochemical data for these three intrusive suites and to discuss the implications of these findings for the Proterozoic evolution of this portion of the South American Platform. A detailed microprobe study of the minerals present in the MC has been presented elsewhere (Preciozzi 1989).

Geological Setting The AGF consists of greenschist facies metasedimentary and metavolcanic rocks which are exposed in a lozenge-shaped area approximately $40 \mathrm{~km}$ in length with a maximum width of $13 \mathrm{~km}$. Detrital metasedimentary rocks (with minor metavolcanic units) constitute the lower and middle sections of the formation and are exposed along the northern and central portions of the outcrop area of the AGF (Fig. 2). The metavolcanic rocks, which constitute the uppermost portion of the AGF, are ex- 

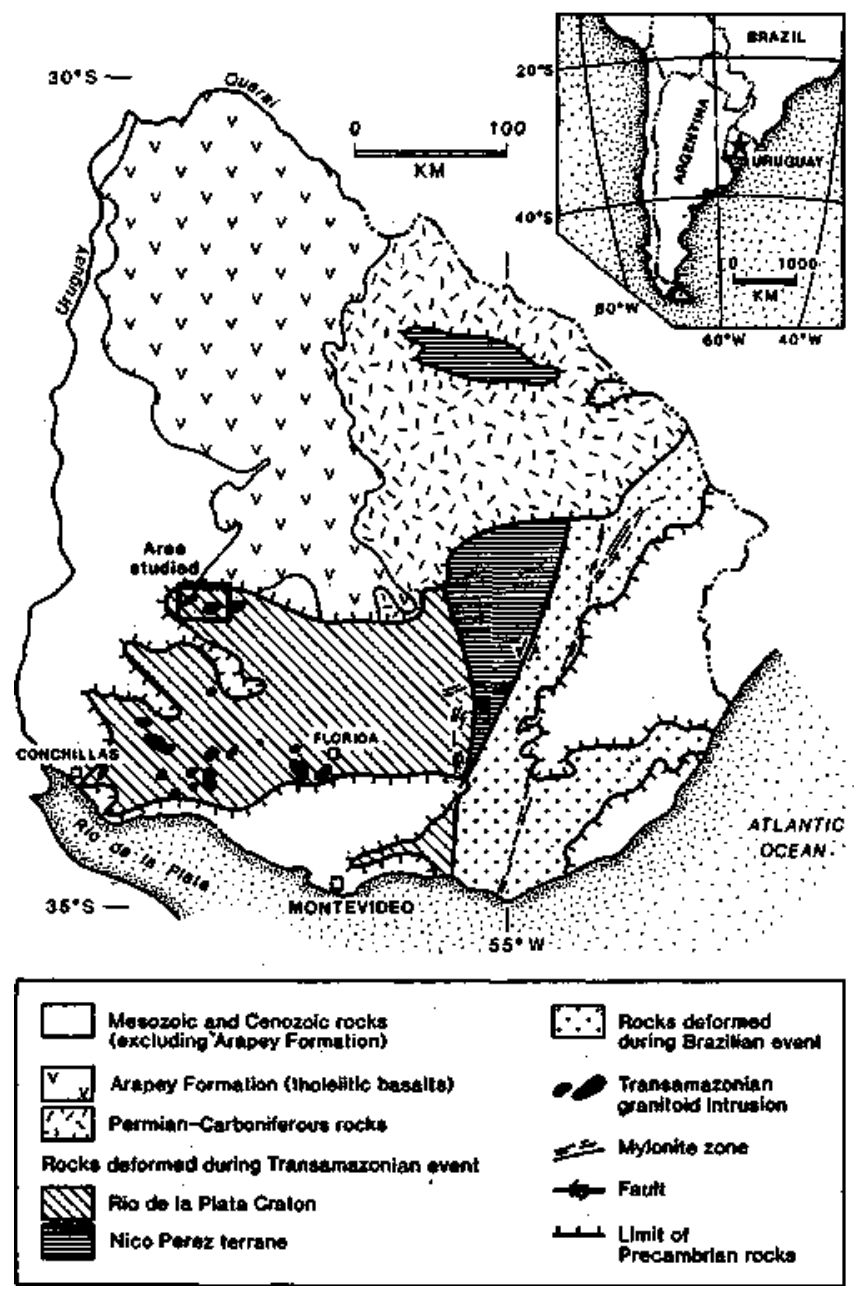

Figure 1 - Geological sketch map of Uruguay showing the location of the study area, central Uruguay

Figura 1 - Esboço geoló gico do Uruguai, com a localização da área estudada, Uruguai Central

posed along the southern margin of the lozenge. Both rock types typically have an overall east-west strike except near the margins of the granites where the schistosity tends to be oriented parallel to the contact of the intrusion. The Paso de Lugo fault, a major structure of considerable linear continuity and east-west orientation, forms the southern boundary of the lozenge, separating it from granitic gneisses and related granitic rocks to the south. The Paso del Puerto fault forms the northwestern boundary of the AGF - the boundary has not been studied in detail in the northeast. It is likely that the whole of the AGF is fault-bounded since the metamorphic grade increases suddenly from greenschist facies to upper amphibolite facies once these faults are crossed. A similar feature has been noted in the Canadian Shield by Card (1990) who suggested that the fault bounded nature of the contacts and the metamorphic discontinuity might be explained by an accreted assemblage of different tectonic terranes. Six different granitic bodies have been intruded into the $\mathrm{AGF}$, the largest of which are the MC and the SG $\left(50 \mathrm{~km}^{2}\right.$ total for both plutons) and the AGP $\left(20 \mathrm{~km}^{2}\right)$. Of the remaining three plutons, the $\mathrm{Yi}$ and Feliciano granites, located to the east of the area considered here, feature well developed planar structures indicating that they have been deformed. The observed foliation in these two plutons appears to correspond to the Dl structures present in the surrounding AGF. We therefore consider these plutons to be syn-tectonic in character with respect to the first major episode of deformation.
It is probable that the Feliciano mass is older than the Yi since the Feliciano has been intruded by a swarm of acid dykes which have not been observed to cross-cut the Yi Pluton. The Carpinteria Pluton is a very small mass of garnetiferous, two-mica leucogranite which is located to the east of the Marincho Complex (Fig. 2). None of these three plutons will be considered further in this report.

PETROGRAPHY Marincho Complex The MC is a crudely circular mass, approximately $8 \mathrm{~km}$ in diameter which is located in the centre of the AGF. It is a composite pluton consisting of three distinctly different components: a. the main unit, which consists typically of grey, biotitehornblende granodiorite, but which ranges in composition from diorite to monzogranite. Both the texture and mineralogy vary rather noticeably from outcrop to outcrop. Plagioclase compositions range from $\mathrm{An}$ in the diorite to $\mathrm{An}$ in the monzogranite. Plagioclase in the more mafic members of the unit are often altered to epidote and sericitc. The potassium feldspar is a perthitic microcline. Myrmekitic intergrowths are frequently observed at the contacts between plagioclase and potassium feldspar. The quartz crystals typically have undulatory extinction. The amphibole is a green hornblende typical of intermediate plutonic rocks (Deer et al. 1966). Biotite contains numerous inclusions of zircon, apatite, titanite and opaque minerals and is spatially associated with hornblende.

The main unit contains enclaves of fine-grained basic material as well as xenoliths derived from the surrounding AGF. The rock is typically massive and there is no evidence of igneous foliation.

b. the hornblendite and associated granodiorite form a NE trending band which crosses the centre of the complex. The hornblendite is typically a porphyritic rock containing coarse-

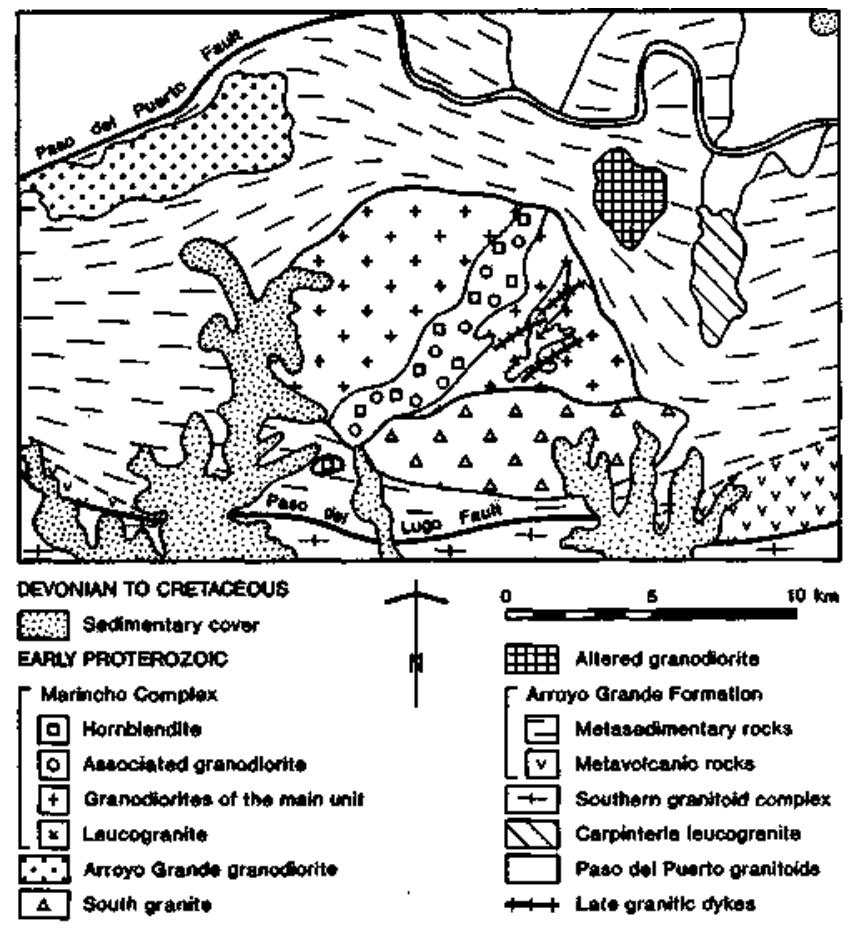

Figure 2 - Sketch map of the local geology showing the locations of the Marincho Complex, the South Granite and the Arroyo Grande Granodiorite. Location of sketch map is shown on figure 1. After Preciozzi (1989)

Figura 2 - Esboço da geologia local, mostrando a localização do Complexo Marincho, do Granito Sul e do Granodiorito Arroyo Grande. A localização deste esboço é mostrada na figura 1 
Table 1 - Chemical analyses of the Arroyo Grande, South Granite and Marincho Complex intrusions. Code for Marincho analyses: $G=$ main portion of the $M C ; L=$ leucogranite; $H=$ hornblendite; $A=$ associated granodiorite; $R$ (in the title line) = rock type.

Tabela 1 - Análises químicas das intrusões do Complexo Marincho, Granito Sul e PJúton Arroyo Grande. Código para as análises do Complexo Marincho: G = porção principal do $\mathrm{MC} ; \mathrm{L}=$ leucogranito; $\mathrm{H}$ = hornblendito; $\mathrm{A}=$ granodiorito associado; $\mathrm{R}$ (na linha de título) = litotipo

\begin{tabular}{|c|c|c|c|c|c|c|c|c|c|c|c|c|c|}
\hline \multicolumn{14}{|c|}{ CHEMICAL ANALYSES OF THF MANMCHO COMPLEX } \\
\hline 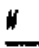 & $\mathbf{R}$ & $\mathrm{SiO}_{2}$ & $\mathrm{TOO}_{2}$ & $\mathrm{Al}_{7} \mathrm{O}_{3}$ & $\mathrm{Fe}_{2} \mathrm{O}_{3}$ & Fô & $\mathrm{MnO}$ & $\mathrm{MgO}$ & $\mathrm{CaO}$ & $\mathrm{Na}_{2} \mathrm{O}$ & $\mathrm{K}_{2} \mathrm{O}$ & $\mathrm{H}_{2} \mathbf{O}$ & Total \\
\hline i & $\mathbf{A}$ & 6000 & 0.60 & 17,80 & 472 & 5.21 & 0.18 & 1.30 & 4.60 & 4.10 & 1.70 & 0.67 & 100.58 \\
\hline 2 & A & 61.90 & 0.60 & 17,50 & 2,98 & 2,90 & 0.07 & 2.30 & 4.70 & 3.85 & 2.40 & 0.58 & 99.78 \\
\hline 3 & A & 62.00 & 0.50 & 17.10 & 4.02 & 2.01 & 0.10 & 1.40 & 4.30 & 3.80 & 1.55 & 0.38 & 100.16 \\
\hline 4 & $\mathbf{L}$ & 74,60 & 0.01 & 14.10 & 0.51 & 0.36 & 0.09 & 0.20 & 0,80 & 4.16 & 2.20 & 1.32 & 98,35 \\
\hline 5 & L & 7490 & 0,01 & 13.50 & 0.49 & 0.73 & 0.18 & 0.15 & 0.90 & 4.25 & 3.16 & 0.52 & 98.79 \\
\hline 7 & $\mathbf{L}$ & 75.00 & 0.05 & 13.40 & 0.59 & 0.63 & 0.12 & 0.05 & 0.95 & 4.05 & 3.36 & 0.60 & 98.80 \\
\hline 8 & $\mathbf{L}$ & 75.00 & 0.05 & 13.20 & 0.95 & 0.15 & 0.08 & 0.30 & 0.50 & 3.70 & 4.60 & 0.68 & 99.21 \\
\hline 9 & $\mathbf{L}$ & 75.30 & 0.05 & 13.00 & 0.92 & 0.08 & 0.08 & 0.35 & 0.45 & 3.85 & 4.50 & 0.65 & 99.23 \\
\hline 10 & $\mathbf{L}$ & 75.60 & 0.01 & 12.80 & 0,90 & 0,01 & 0.08 & 0,20 & 0.60 & 3.75 & 4.60 & 0.62 & 99.17 \\
\hline 11 & H & 50.10 & 0.85 & 12.70 & 3,83 & 6.37 & 0.16 & 11.00 & 10.00 & 2.45 & 1.10 & 1.14 & 99.70 \\
\hline 12 & H & $\$ 2.20$ & 0.60 & 10.40 & 4.82 & 4.49 & 0.16 & 10.70 & 10.90 & 2.00 & 1.00 & 2.17 & 99.44 \\
\hline 13 & $\mathbf{H}$ & 52.80 & 0.60 & 11.80 & 3.67 & 5.07 & 0.16 & 10.60 & 10.40 & 235 & 1.10 & 0.69 & 99.24 \\
\hline 14 & H & 56.70 & 0.50 & 9.00 & 2.79 & 5.50 & 0.23 & 11.30 & 10.70 & 2.20 & 0.70 & 0.86 & 100.48 \\
\hline 16 & 0 & 61.90 & 0.85 & 16.50 & $1.6 \mathrm{I}$ & 3.16 & 0.12 & 2.45 & 5,15 & 480 & 1.30 & 0.53 & 98.37 \\
\hline 17 & $\mathbf{a}$ & 62.90 & 0.80 & 16.30 & 1.41 & 3.06 & 0.09 & 2.35 & 5.05 & 470 & 1.20 & 0.51 & 98.37 \\
\hline 18 & $\mathbf{G}$ & 63.00 & 0.80 & 16.20 & 1.21 & 3.26 & 0.08 & 2.55 & 4.85 & 480 & 1.10 & 0.56 & 98.41 \\
\hline 19 & 0 & 66.00 & 0.70 & 1480 & 2,57 & 1.74 & 0.04 & 2.30 & 3.60 & 3.70 & 3.60 & 0.61 & 99.66 \\
\hline 20 & 0 & 66.50 & 0.60 & 1450 & 2.40 & 2.61 & 0,05 & 230 & 3.40 & 3.60 & 4.10 & 0.58 & 100.64 \\
\hline 21 & $\mathbf{0}$ & 66.50 & 0.70 & 1430 & 2.47 & 1.84 & 0.04 & 2.40 & 3.70 & 3.90 & 3.40 & 0.71 & 99.96 \\
\hline 22 & 0 & 66.50 & 0.80 & 15,60 & 1.38 & 212 & 0.10 & 1.40 & 3.00 & 3.70 & 490 & 0.7 & 100.20 \\
\hline 23 & 0 & 66.80 & 0.70 & 14.60 & 2.47 & 1.70 & 0.07 & 2.00 & 3.44 & 3.75 & 3.40 & 0.25 & 99.18 \\
\hline 24 & 0 & 67.10 & 0.75 & 14.50 & 2.37 & 1.54 & 0.02 & 2.15 & 3.45 & 3.60 & 3.55 & 0.73 & 99.76 \\
\hline 25 & 0 & 67.30 & 0.80 & 14.70 & 1.58 & 1.92 & 0.10 & 1.50 & 2.90 & 3.90 & 4.70 & 0.68 & 100.08 \\
\hline 26 & 0 & 67.50 & 0.55 & 13.50 & 2.60 & 2.41 & 0.10 & 2.40 & 3.30 & 3.75 & 3.95 & 0.78 & 300.84 \\
\hline 27 & 0 & 67.50 & 0.78 & 14.60 & 1.48 & 2.02 & 0.08 & 1.45 & 2.82 & 3.85 & 4.00 & 0.72 & 99.30 \\
\hline 28 & 0 & 67.86 & 0.70 & 14.60 & 1.68 & 1.82 & 0.05 & 1.55 & 3.20 & 4.15 & 3.55 & 0.48 & 99.64 \\
\hline 29 & $\mathbf{G}$ & 67.96 & 0.70 & 15.30 & 1.58 & 1.62 & 0.05 & 1.55 & $\mathbf{3 , 3 0}$ & 3.85 & 3.20 & 0.47 & 99.58 \\
\hline 30 & $\mathbf{G}$ & 68.70 & 0.73 & 14.30 & 1.38 & 1.82 & 0.05 & 1.30 & 2.80 & 3.70 & 3.90 & 0.72 & 99.42 \\
\hline 31 & 0 & 68.96 & 0.65 & 14.30 & 1.58 & 1.72 & 0.05 & 1.45 & 3.10 & 4.05 & 3.25 & 0.47 & 99.58 \\
\hline
\end{tabular}

CHEMICAL ANAEYSES OF THE SOUTH GRANTTE

\begin{tabular}{|c|c|c|c|c|c|c|c|c|c|c|c|c|}
\hline 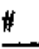 & $\mathrm{SiO}_{2}$ & $\mathrm{TO}_{2}$ & $\mathrm{Al}_{2} \mathrm{O}_{3}$ & $\mathrm{Fe}_{2} \mathrm{O}_{3}$ & FeO & $\mathrm{MLO}$ & $\mathrm{MgO}$ & $\mathrm{CaO}$ & $\mathrm{M}_{\mathbf{i}_{2}} \mathrm{O}$ & $\mathrm{K}_{2} \mathrm{O}$ & $\mathrm{H}_{2} \mathrm{O}$ & Total \\
\hline 1 & 71.80 & 0.60 & 1480 & 1.38 & 0.85 & 0.05 & 0.72 & 2.10 & 4.05 & 3.60 & 0.72 & 100.67 \\
\hline 2 & 72.50 & 0.50 & 14.60 & 1.28 & 0.75 & 0.10 & 0.70 & 2.05 & 3.95 & 3,30 & 0.25 & 100,18 \\
\hline 3 & 73.00 & 0.20 & 14.70 & 1.48 & 0.60 & 0.05 & 0.65 & 2.10 & 3.40 & 3.75 & 0.42 & 100.35 \\
\hline 4 & 73.20 & 0.30 & 14.70 & 1.38 & 0.65 & 0.01 & 0.60 & 2.00 & 3.75 & 3,40 & 0.56 & 100.55 \\
\hline 5 & 73.50 & 0.45 & 14.30 & 1.33 & 0.24 & 0.01 & 0.50 & 2.00 & 4.30 & 3.20 & 0.71 & 100.54 \\
\hline 6 & 73.80 & 0.40 & 14.40 & 1.18 & 0.65 & 0.01 & 0.52 & 1.90 & 3.75 & $\mathbf{3 . 3 0}$ & 0.52 & 100.43 \\
\hline 7 & 74,50 & 0.25 & 14.40 & 1.18 & 0.45 & 0.05 & 0.50 & 1.75 & 3.60 & 3,20 & 0.57 & 100.45 \\
\hline 8 & 75.20 & 0.05 & 14,2 & 0.25 & 0.15 & 0.01 & 0.21 & 0.30 & 3.45 & 6.10 & 0.48 & 100.40 \\
\hline 9 & 75.40 & 0.01 & 14.00 & 0.40 & 0.01 & 0.01 & 0.11 & 0.40 & 3.65 & 5.90 & 0.36 & 100.25 \\
\hline 10 & 7600 & 0.05 & 13.80 & 0.30 & 0.10 & 0.01 & 0.05 & 0.36 & 3.60 & 5.85 & 0.27 & 100.39 \\
\hline
\end{tabular}

CHEMICAL ANALYSES OF THE ARROYO GRANDE PLUTON

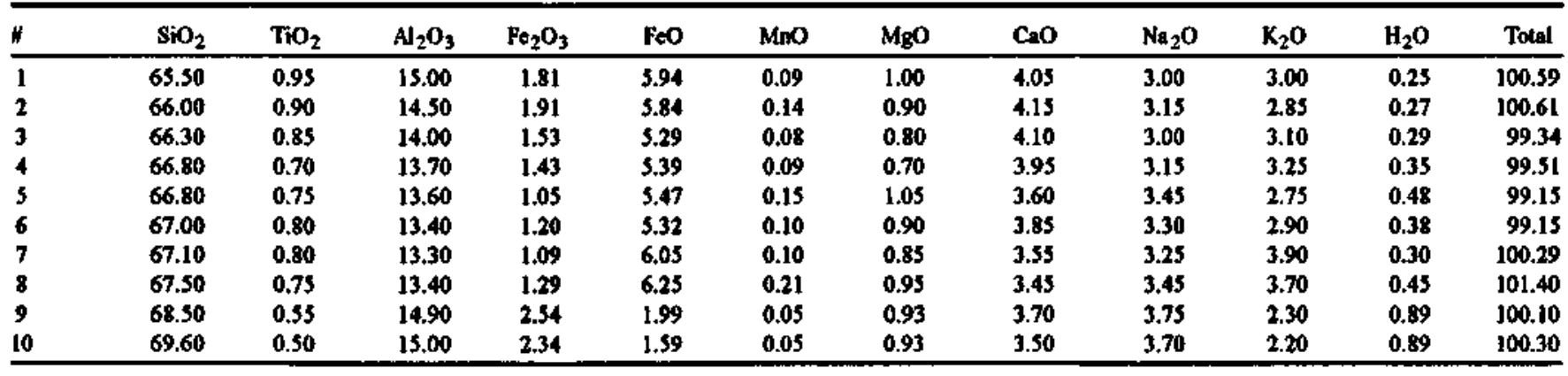





Figure 3 - P-Q classification diagram for the Arroyo Grande Pluton (3a) and theMarincho Complex and the South Granite (3b). Diagram after Debon and LeFort (1983). I = syenogranite; 2 = monzogranite; 3 = granodiorite; $4=$ tonalite; $8=$ quartz diorite; filledcircle $=A G P$; open triangle $=S G ;$ diamond $=M C$ leucogranite; open box $=M C$ main unit; open circle $=M C$ hornblendite and related rocks Figura 3 - Diagrama classificatório P-Q para o Plúton Arroyo Grande (3a) e 0 Complexo Marincho e Granito Sul (3b). Diagrama a partir de Debon \& Le Fort (1983). 1 = sienogranito; 2 = monzogranito; 3 = granodiorito; 4 . tonalito; $8=$ quartzo diorito; círculo cheio $=\mathrm{AGP}$; triângulo vazado $=\mathrm{SG}$; losango $=$ leucogranito $\mathrm{MC}$; quadrado vazado = unidade principal do $\mathrm{MC}$; círculo vazado $=$ homblendito e rochas relacionadas do $\mathrm{MC}$

grained, euhedral dark green hornblende and also mediumgrained subhedral pale green hornblende. Clinopyroxene is present, either as independent grains or as relicts surrounded by the dark green hornblende. A concentration of opaque minerals is frequently observed at the contact between the relict clinopyroxene and the amphibole. Plagioclase compositions vary from $\mathrm{An}_{52}-\mathrm{An}_{56}$. The plagioclase is typically altered to a fine-grained assemblage of pistachite (pleochroic yellow epidote) and clinozoisite.

A "granodioritic" unit, whose composition ranges from diorite to monzogranite, is intimately associated with the hornblendite. Although superficially similar to the main unit granodiorite, Fernandez \& Preciozzi (1974) observed that the plagioclase compositions are systematically more sodic in the main unit granodiorites. The plagioclase compositions vary from $\mathrm{An}_{52}$ in the dioritic members of this unit to $\mathrm{An} 25$ in the monzogranitic members. The mineralogy and textures exhibited by this unit are comparable to those observed in main unit rocks.

The rocks of this unit are clearly intrusive into the rocks of the main unit described above. A well developed igneous foliation, defined by aligned hornblende crystals, is present near the contact with the rocks of the main unit.

c. a leucogranite unit forms a mappable mass of irregular form in the east central portion of the complex. It is completely surrounded by main unit rocks and is intrusive into it. The plagioclase is zoned and varies in composition from An8 in the core of the crystals to An2 at the margin. The potassium feldspar is a perthitic microcline and the quartz features undulatory extinction. Biotite, generally associated with primary muscovite, is the main mafic mineral present. The accessory minerals include garnet, prismatic apatite and bypyramidal zircon. Small pegmatitic segregations were observed in the field which suggests that this particular unit of the $\mathrm{MC}$ was fluid saturated during crystallization. Enclaves are very rare in this unit.

d. a set of leucogranite dykes featuring hypidiomorphic granular textures. They are intrusive into the eastern portion of the MC (leucogranitic member as well as the main unit). They contain oligoclase, perthitic microcline and quartz as the main minerals. The principal accessory minerals are biotite, garnet (relatively abundant), zircon, titanite, apatite and opaque minerals.

The South Granite (SG) The SG, which is located immediately adjacent to the $\mathrm{MC}$, features massive, granitic to porphyritic textures except at the contact between either the AGF or the rocks of the main unit where cataclastic to mylonitic textures are observed. Biotite forms irregular crystals which have been partially replaced by chlorite. Potassium feldspar is a perthitic microcline and the plagioclase is sodic oligoclase in composition. Quartz crystals typically feature undulatory extinction and have mortar texture developed along intergrain contacts. Enclaves and xenoliths of the surrounding rock types are notably absent.

Arroyo Grande Pluton (AGP) The AGP exhibits a much more restricted petrographic range than does the $\mathrm{MC}$, varying in composition from granodiorite to monzogranite. Biotite is deep brown in colour and is spatially associated with hornblende. The plagioclase composition varies from An32 in the granodiorite to $\mathrm{An}_{16}$ in the monzogranite. The potassium feldspar is a perthitic microcline.

The pluton is somewhat elongate in form and appears to be spatially related to the Paso del Puerto Fault.

Geochemistry A total of 31 analyses of the MC and SC and 10 of the AGP are presented in Table 1.

The validity of the petrographic terms applied to the samples of both suites is apparent on the P-Q plots (Fig. 3a and $3 b$ ) proposed by Debon \& LeFort (1983). The AGP (Fig. 3a) exhibits a much more restricted compositional variability and is largely confined to the granodiorite field. The trend defined by the data points is parallel to that defined by the granodiorites of the main unit of the $\mathrm{MC}$.

The MC suite defines a broad band of data points which sweeps across figure $3 \mathrm{~b}$ from the quartz diorite to the syenogranite fields with the majority of samples falling in the granodiorite or monzogranite domains. Two trends are crudely apparent on the diagram, the first defined by the hornblendite and associated granodiorites as well as the granodioritic rocks of the main unit. The $\mathrm{Q}$ values for these rocks increase from 50 in the quartz diorites to approximately 150 in the granodiorites and then decline to 100 in the more evolved granitic rocks. The second trend is defined by those 


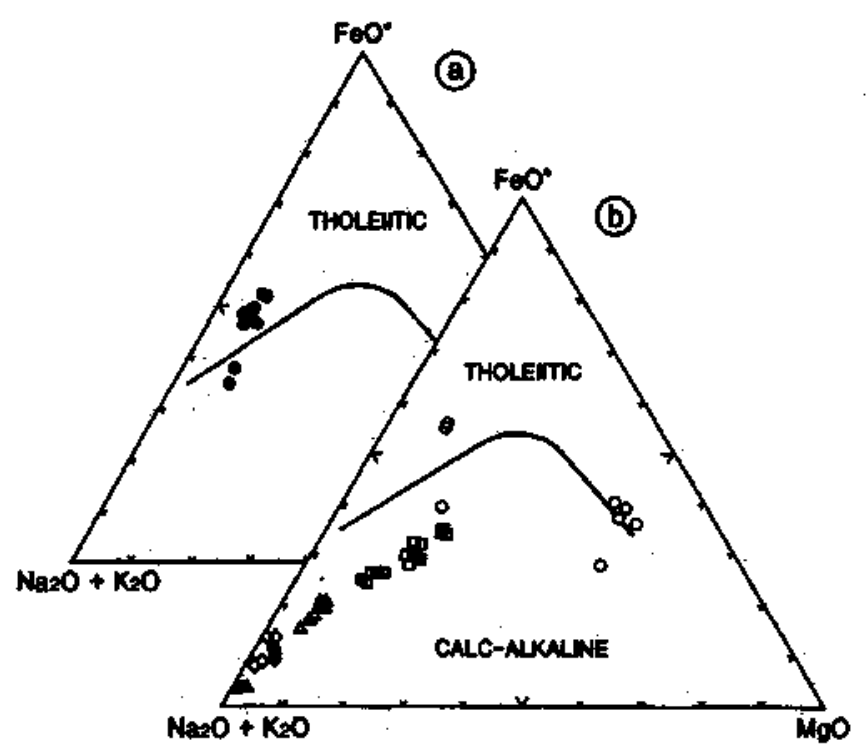

Figure 4 - AFM diagram for the AGP (4a) and the $\mathrm{A} / \mathrm{C}$ and $S G(4 b)$. Limit between calc-alkaline and tholeiitic fields taken from Irvine andBaragar (1971). Symbols as on figure 3 Figura 4 - Diagrama AFM para o AGP (4a) e o MC e SG (4b). 0 limite entre os campos toleíticos e cálcio-alcalino é oriundo de Irvine \& Baragar (1971). Simbologia como na figura 3

rocks which were mapped in the field as MC "leucogranites" (and related rocks). The data points for these rocks define a trend parallel to the second part of the first trend however it is situated at much higher $Q$ values, which fall from 225 in the granodioritic members of the unit to 180 in the more evolved members. This observation is mirrored in the normative mineral contents of these two groups of rocks. The leucogranites have normative quartz contents which decline from $40 \%$ to $35 \%$ in the more evolved members whereas the rocks defining the first trend rarely have normative quartz values which surpass $25 \%$.

The SG rocks define a crudely triangular area on Figure $3 \mathrm{a}$ and no trend is apparent. In common with the MC leucogranite, the SG is also characterized by relatively high $Q$ values.

Both the AGP and the main unit of the MC are metaluminous, showing very little variation in the peraluminous index, $(\mathrm{PI}=\mathrm{A} / \mathrm{CNK}=0.90$ in both cases $)$. All but two of the 26 analyses for these two groups of rocks have values less than 0.95 and all have values less than 1.01 . The SG is mildly peraluminous - PI ranges from 1.03 to 1.15 and increases with increasing $\mathrm{SiO}_{2}$. The leucogranitic unit of the $\mathrm{MC}$ is considerably more peraluminous - PI values range from 1.04 to 1.32 and decline with increasing $\mathrm{SiO}_{2}$ The high PI values are related to relatively low $\mathrm{K}_{2} \mathrm{O}$ contents in some of the leucogranites.

The MC suite of rocks appears to collectively define a typical calc-alkaline trend on the igneous AFM diagram of Irvine and Baragar (1971, Fig. 4b). All but two samples are either within or very close to the line separating the calcalkaline and tholeiitic domains. Data for the AGP define a trend which straddles the tholeiitic and calc-alkaline fields.

Geochronology Five Rb-Sr whole rock age determinations have been carried out on these intrusions, (Tab. 2, Fig. $5)$. All analyses were carried out in the laboratories of the University of Clermont-Ferrand, Clermont-Ferrand, France, and were effected using isotope dilution, a technique of considerable precision (see small la errors in Tab. 2), which has as a result that the MSWD values are relatively large.
Thus, the fact that the MSWD values are greater than 30 for three of the five analyses does not mean that the data reported below are errorchrons. The ages were calculated using a slightly modified version of the program of York (1966).

The first of these from the late leucogranite dykes which cut the eastern part of the MC, yielded an age of 1,969 \pm 25 $\mathrm{Ma}$ (initial ratio 0.734 ), The high initial ratio for these rocks suggest that this intrusive unit almost certainly formed by partial melting of rather old gneissic crust.

The leucogranite unit of the MC yielded an age of 2,067 \pm $24 \mathrm{Ma}$ (initial ratio 0.719 ). This initial ratio is also very high and indicates that the melt is of totally crustal origin.

The relatively high initial ratio for the main portion of the MC $(2,291 \pm 65 \mathrm{Ma}$; initial ratio 0.714) suggests that this unit is also of crustal origin, although not necessarily from the same source area.

The South Granite gave an age of $2.180 \pm 50 \mathrm{Ma}$ (initial ratio 0.709 ). The origin of the South Granite magma is less certain. It may have formed totally by partial melting of lower continental crust or by a significant amount of contamination of a mantle-derived melt by crustal material.

The difference in both the ages, and to a lesser extent the initial ratios, suggest that all these rocks should be considered to have evolved relatively independently of one another.

The data for the granitic blocks found within the Paso de Lugo Fault Zone (2,544 $\pm 38 \mathrm{Ma}$; initial ratio 0.7073) demonstrate the presence of Archean crust in the area at this time. Furthermore, the initial ratio is rather high, and therefore it is reasonable to propose that crustal material was incorporated in the magma at some point. This crustal material must obviously have been older than the age of the granitic blocks. Another late Archean age determination on blocks in a similar tectonic setting has been reported by

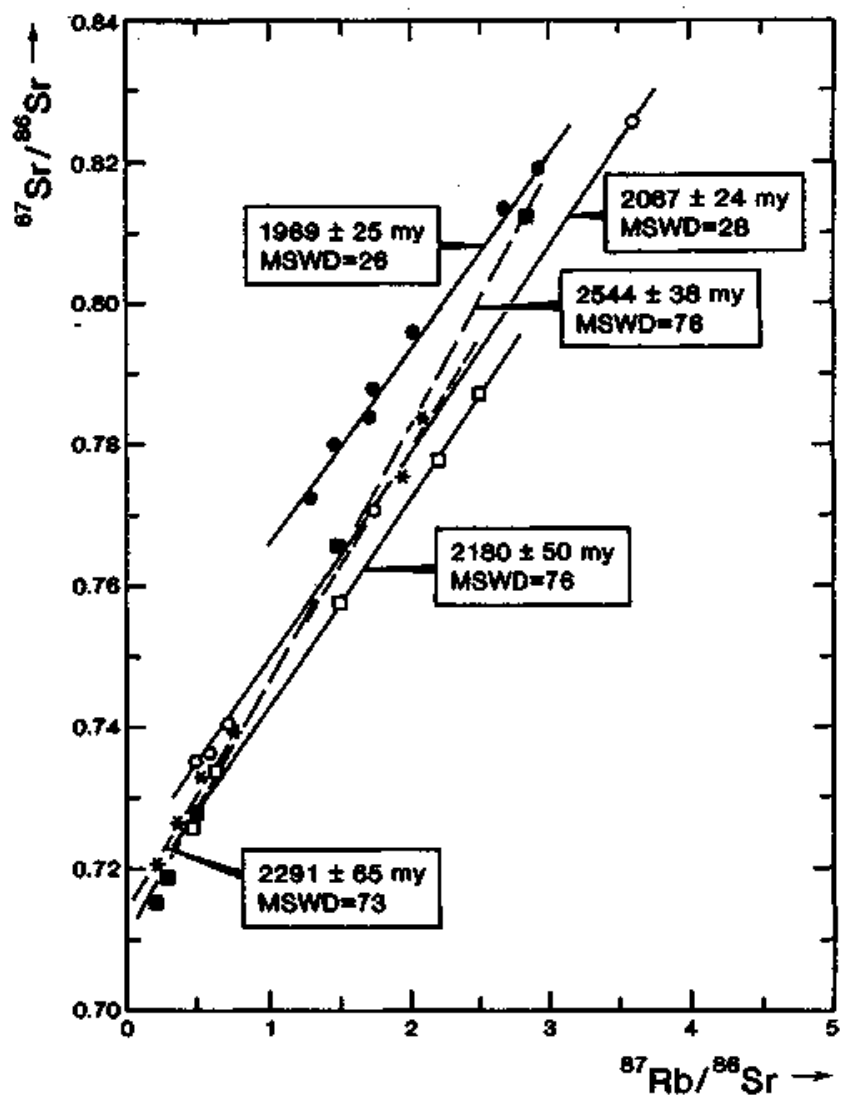

Figure 5-Isochrons for the plutonic rocks analyzed in this report

Figura 5 • Isócronas para as rochas plutônicas analisadas neste trabalho 
Preciozzi (1992) $(2,501 \pm 112 \mathrm{Ma}$; initial ratio 0.7003). In this latter case, the low initial ratio suggests that the primary magma was derived by partial melting of previously depleted mantle material (previously melted between 2,800 and 3,000 Ma?).

Table 2 - Results of radiometric age determinations for the Marincho Complex (MC) and the South Granite (SG) suites Tabela 2 - Resultados de determinações radiométricas para suítes do Complexo Marincho e Granito Sul

\begin{tabular}{|c|c|c|c|c|c|}
\hline Suite & $\mathrm{Rb} 87 / 8 \mathrm{~s} 86$ & 1 sigma & $8+87 / S+86$ & 1 sigmta & age \\
\hline Mc-1 & 2907 & 0.0027 & 0.81995 & 000012 & $1969 \pm 25 \mathrm{Mm}$ \\
\hline BtCL-2 & 2709 & 0.0056 & 0.81435 & 000011 & \\
\hline MCL-3 & 1.457 & 0.0021 & 078017 & 000026 & $M S W D=26$ \\
\hline $\mathrm{AHCH} 4$ & 1.725 & 0.0012 & 0.7421 & 0.00019 & \\
\hline kA-5 & 2082 & 0.0027 & 0.79725 & 000032 & $\mathrm{IR}=0.734$ \\
\hline MCL-6 & 1.809 & 0.0036 & 0.787 & 0.00013 & \pm 0.003 \\
\hline Ma-7 & 1.302 & 0.0052 & 0.7399 & 0,00007 & \\
\hline LGR-1 & 0.512 & 0.0021 & 0.73505 & 0.00015 & $2067 \pm 2 \mathrm{Mh}$ \\
\hline LGR.2 & 0.623 & 0.0017 & 0.73601 & $0,0003]$ & \\
\hline LOR-3 & 0751 & 0.0004 & $0.7400 \mathrm{~B}$ & 0.00022 & $M S W D=2 A$ \\
\hline LGR-4 & 1.756 & 0.0016 & $0.7 m s 2$ & 000011 & $\mathrm{R}=0.719$ \\
\hline LOR-S & 3.582 & 0.0033 & 0.82561 & 0.00013 & \pm 0.001 \\
\hline GRs-1 & 0.496 & 0.0032 & 0.72657 & 0.00026 & $2180 \pm \$ 0 \mathrm{Mn}$ \\
\hline GRS-2 & 0.802 & 0.0012 & 0.73365 & 000009 & \\
\hline CRS-3 & 1.596 & 0.0024 & 0.75801 & 0.00052 & $M S W D=76$ \\
\hline GRS-4 & 2260 & 0.0015 & 0.77854 & 000011 & $\mathrm{IR}=0.769$ \\
\hline ORs-5 & 2,489 & 0,0021 & 0.78851 & 000015 & \pm 0.003 \\
\hline GDP-1 & 0273 & 0005 & 0.72017 & 000017 & $2201 \pm 65 \mathrm{M}$ \\
\hline GDP.2 & 0387 & 0.0013 & 0.72631 & 0.00027 & \\
\hline GDP-3 & 0611 & 0.0018 & 0.73512 & 0.00011 & MSWD $=73$ \\
\hline GDP-A & 0767 & 0.0007 & 0.74007 & 0.00041 & \\
\hline CDP-5 & 1.965 & 0.0033 & $0 \pi / 314$ & 0.00023 & $\mathrm{IR} \pm 0.714$ \\
\hline GDP-6 & 2026 & 0.0012 & 0,78024 & 0,00017 & $\pm 0,602$ \\
\hline BOR-1 & 0.251 & 0.0015 & 0.71605 & 0,00021 & $2544 \pm 38 \mathrm{Ma}$ \\
\hline BGR-2 & 0374 & 0.0022 & 0.71960 & 0.00019 & \\
\hline BGR-3 & 0.501 & 0.0031 & 0.72517 & 0.00043 & $M S W D=76$ \\
\hline BGR-4 & 1.126 & 0,0011 & 0.75000 & 000010 & \\
\hline BGR-5 & 1.655 & 0.0014 & 0.76651 & 000017 & $\mathrm{IR}=0.70 \mathrm{~T}$ \\
\hline BGR-6 & 2887 & 0.0017 & 0.81350 & 0.00009 & \pm 0.602 \\
\hline
\end{tabular}

MCL: late leucogranite dykes cross-cutting the Marincho Complex

LGR: leucogranite unit of the Marincho Complex

GRS: South Granite

GDP: Main portion of the Marincho Complex

BGR: Granite blocks located within the Paso de Lugo Fault Zone

Note: errors on the initial ratios are 2 sigma errors

\section{Discussion}

a. Pressure of emplacement Experimental studies in the water saturated haplogranitic quartz - albite - orthoclase system can be used to estimate the pressure of emplacement of granitic plutons since the position of the experimental minimum in this system varies as a function of pressure. Only the most evolved compositions can be used in order to reduce uncertainty due to the presence of $\mathrm{Ca}$ in plagioclase. In addition it is required that fluid-saturated conditions were attained during crystallization (i.e., that $\mathrm{P}_{\mathrm{H} 2 \mathrm{O}}=\mathrm{P}_{\text {Total }}$ ). The presence of pegmatitic segregations in the leucogranite unit indicates that the assumption of fluid-saturated conditions is reasonable for this unit, however no such supporting evidence was observed in the SG. We have retained only those analyses for which the normative quartz + albite + orthoclase contents surpass $95 \%$. Results are shown on figure 6 . The MC leucogranites all plot very close to the $1 \mathrm{~kb}$ minimum which can be taken as the pressure of crystallization of this mass, and therefore of the MC as a whole.

The analyses of the South Granite are not close to the trajectory of minimum melt compositions. This may be due to the fluid-undersaturated nature of the magma combined with the presence of another component, such as $\mathrm{CO}_{2}$, in the fluid phase. Ebadi and Johannes (1991) have shown that addition of $\mathrm{CO}_{2}$ displaces minimum melt compositions to more orthoclase-rich values. In any case the data for the South Granite are such that the pressure of emplacement cannot be determined in this manner.

b. Classification of the tectonic setting A number of tectonic (discriminant diagrams for granitic rocks have been proposed in recent years, however only two make use of the major element data. Application of the approach of Maniar and Piccoli (1989) suggests a fundamental difference in the environment of emplacement of the AGP and the MC rocks, (Figs. 7a and 7b). The AGP analyses mainly fall above the crudely horizontal line which crosses the diagram, placing them in the extensional granite field. The MC hornblendites and associated granodiorites, as well as the main unit granodiorites, all fall below this line in the collisional granite field. The low value of the peraluminous index for these units of the $\mathrm{MC}$ rocks enables the CCG environment to be eliminated from further consideration, however the data do not permit discrimination between the IAG and CAG environments using the Maniar and Piccoli method.

Analyses of both the leucogranite and the SG fall either within or very close to the post-orogenic granite field. It is commonly observed that the evolved members of granitic suites of whatever origin tend towards this field. Since neither of these two plutons has an associated basic component, they cannot be uniquely associated with a specific tectonic environment.

Batchelor \& Bowden (1985) used the $\mathrm{R}_{1}-\mathrm{R}_{2}$ diagram originally proposed by LaRoche et al. (1980) as a tectonic discriminant diagram (Figures 8a and 8b). Analyses of the AGP plot near the limit between the pre-plate collision field and the syn-collision field. The problem is thus similar to that discussed with reference to figure 7 ; the evolved members of any of the chemical trends which originate in field 2 through 5 all plot in field 6 . Thus samples which only plot in or very near to field 6 could belong to any chemical trend, and there-

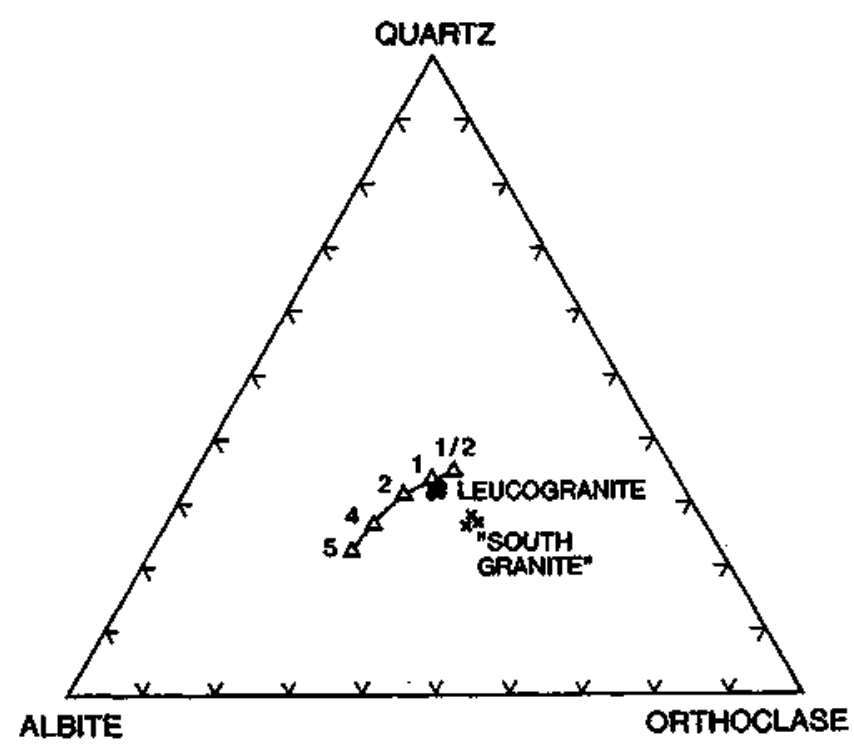

Figure 6 - Normative quartz-albite-orthoclase diagram for the most evolved plutonic analyses from the Marincho Complex and the South Granite. Location of minimum melt compositions taken from Winkler (1979)

Figura 6 - Diagrama quartzo-albita-ortoclásio normativos para as análises mais evoluídas do Complexo Marincho e Granito Sul. A localização das composições de fusão mínima foram tomadas de Winkler (1979) 

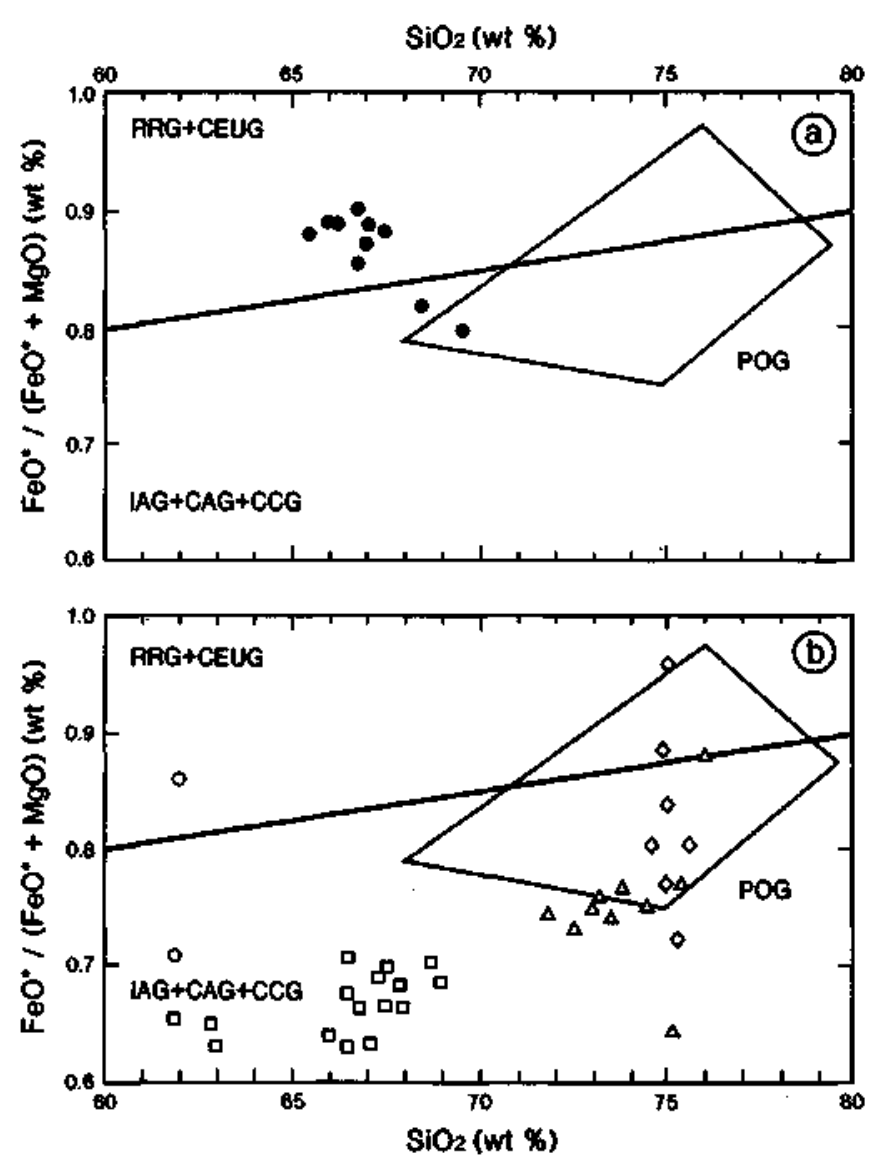

Figure $7-\mathrm{FeO}^{*} /(\mathrm{FeO} *+\mathrm{MgO})-\mathrm{SiO}_{2}$ plot for the $\mathrm{AGP}(7 \mathrm{a})$ and the $M C$ and $S G$ (7b). Symbols as on figure 3. CEUG (continental epeirogenic uplift granite); $R R G$ (rift related granite); IAG (island arc granite); $C A G$ (continental arc granite); $C C G$ (continental collision granite); POG (post orogenic granite)

Figura 7 - Diagrama $\mathrm{FeO} *(\mathrm{FeO} *+\mathrm{MgO})-\mathrm{SiO}_{2}$ para o AGP (7a) e MC e SG (7b). Simbologia como na figura 3. CEUG (granito de soerguimento epirogênico continental); RRG (granito relacionado com rift); IAG (granito de arco insular); CAG (granito de arco continenal); POG (granito pós-orogênico)

fore to any one of the associated tectonic environments. We note that a pre-tectonic environment is not favoured by the field evidence - the massive nature of the plutons suggests a late-tectonic to post-tectonic timing of emplacement although there are numerous exceptions to this statement.

The MC analyses (excluding the hornblendites) plot in a crudely circular area on the diagram which straddles the preplate collision and post-collision uplift domains and is therefore not definitive. The SG and the leucogranites plot in the syn-collision to post-orogenic fields which is in agreement with their positions on figure 7 .

c. Timing of intrusion The proposed ages for the SG, the late dykes, and the different units of the MC clearly indicate that none of these intrusions are in any way related. The cataclastic nature of the contact between the SG and all surrounding rocks indicates a faulted contact for this particular mass. However the contact between the hornblendite, the rocks of the main unit and the leucogranite are all demonstrably intrusive with no evidence of faulting being present between them.

Two possible models can be proposed to explain the relationship between the hornblendite and the main unit of the $\mathrm{MC}$. The first is that the hornblendite and the associated granodiorites are in no way related to the main unit. The field evidence, which clearly indicates that the hornblendite is younger than the main unit supports this hypothesis. However there are many examples in the geological literature of multiphase intrusions in which a partially evolved, relatively high-level magma chamber is invaded by a second surge of more primitive, but co-magmatic material from depth, followed by mixing between the two components. This possibility cannot be discounted here, and additional isotopic data will be required to resolve this dilemma.

The high initial ratio of the leucogranite dykes (0.734) clearly indicates that this unit crystallized from a melt which was derived by partial melting of middle to upper crustal level material. It is certain that the heat necessary to provoke partial crustal melting originated from a source other than the main portion of the MC itself since the age of the leucogranite dyke is significantly younger than any component of the MC.

d. Comparison with the southern portion of the Uruguay Crystalline Belt The plutpnic rocks described in this article are very similar to those in southern Uruguay described in Preciozzi \& Bourne (1992). In both areas, granitoid rocks have been emplaced into a series of greenschist facies schists. Additionally, three periods of pluton emplacement appear to have occurred in both areas. The age of the South Granite $(2,180 \pm 50 \mathrm{Ma})$ is similar to the reported ages of 2,225 \pm 25 Ma for the leucogranite member of the Arroyo de la Virgen Pluton and 2,290 $\pm 35 \mathrm{Ma}$ age for a granitic member of the Isla Mala Pluton, (Preciozzi \& Bourne, 1992). All three of these rocks have moderate initial ratios which range from 0.708 to 0.709 ). Furthermore all three plutons are massive, which suggests that they were emplaced after the peak of the greenschist facies metamorphic event had been attained. By contrast, the Feliciano and Yi granites feature a well developed foliation; a date on either of these rocks will enable a maximum age for the greenschist facies metamorphism to be established. Foliated plutons such as the Feliciano and the Yi intrusions have also been identified in the San José Belt (SJB) of southern Uruguay.

The age of the leucogranitic member of the Marincho Complex $(2,067 \pm 24 \mathrm{Ma})$ is considerably younger than any of the abovementioned plutons, however it is similar in age to the 2,040 $\pm 40 \mathrm{Ma}$ Isla Mala granite dyke discussed by Preciozzi and Bourne (1992). The ages of the late granitic dykes are also comparable with those from southern Uruguay (1,925 $\pm 23 \mathrm{Ma}$ and 1,894 \pm 75 Ma-Preciozzi \& Bourne 1992).

e. Contributions to a tectonic model Bossi (1983) proposed a sequence of events for the pre-Devonian rocks of Uruguay as follows:

1. development of a cratonic area of rocks older than 2,050 Ma located to the north of the AGF.

2. deposition of the AGF (and other similar units such as the Paso Severino Formation further south) in ENE trending zones 3. metamorphism of variable intensity and granite intrusion between 2,050 Ma and 1,800 Ma. He suggested that syntectonic granites developed in the high-grade zones whereas post-tectonic intrusions were contemporaneously emplaced into the low-grade zones. This period of deformation and intrusion is known as the "Ciclo Orogénico Antiguo" (COA).

The data presented here and elsewhere (Preciozzi \& Bourne 1992) suggest that the sequence of events proposed by Bossi must be somewhat modified. In particular, the geochemistry and available geochronology of the granitoid rocks suggest that the COA may be subdivided into three phases.

The first phase (of inferred Archean age) is believed to be related to the greenschist facies metamorphism. The marked planar structures and other structural elements observed in the Feliciano and Yi granites suggest that they 
should be considered as syn-tectonic with the main deformational phase of the AGB. The granodiorite unit of the Isla Mala Complex, located in the SJB of southern Uruguay, has been dated at 2,450 $\pm 40 \mathrm{Ma}$ (Preciozzi 1993). This intrusion is not foliated and appears to be of post-metamorphic age.

Several blocks of massive alkali granite, which are found within the Paso de Lugo fault zone, have been dated at 2,501 $\pm 112 \mathrm{Ma}$ (initial ratio 0.7003; Preciozzi 1992) and 2,544 \pm $38 \mathrm{Ma}$ (initial ratio 0.7073). The fact that both the Isla Mala Complex granodiorite and the alkali granite blocks are massive indicates that the deformation which affected the volcano-sedimentary belts was still older. If one accepts the age limit of 2,500 Ma to separate the Archean from the Proterozoic, then the greenschist facies and related deformation which affected the AGB was definitely of Archean age.

The second phase, is represented both in the AGB and the SJB by a number of intrusions whose ages range from 2,290 Ma to 2,180 Ma. The older rocks, such as the MC granodiorite feature a calc-alkaline chemistry whereas the younger members of the group, such as the Arroyo de la Virgen Pluton (2,225 Ma - Preciozzi \& Bourne 1992) are alkaline in nature. This suggests a gradual transition between a syn-collisional and a post-collisional environment over a period of approximately $110 \mathrm{Ma}$.

A third phase of intrusive activity developed between 2,040 Ma and 1,894 Ma in both the AGB and the SJB. These rocks are small dykes which are intrusive into the plutonic rocks developed during phase 2 . Once again, the older members of the group feature a calc-alkaline chemistry whereas the younger ones are alkaline. The AGP is defmately alkaline, however no date is yet available for this intrusion.

The Mahoma granite, located to the west of the area investigated here, has been dated at 1,935 Ma (Umpierre \& Halpera 1971). This shows that the intrusive rocks developed during this intrusive episode are not necessarily all small dykes. The leucogranite member of the MC probably developed at this stage as well.

\section{CONCLUSION}

1. The age of emplacement for five granitoid intrusions were determined as follows:

- granitic blocks in the Paso de Lugo fault: 2,544 $\pm 38 \mathrm{Ma}$

- Marincho Complex granodiorite: 2,291 $\pm 65 \mathrm{Ma}$

- South granite: $2,180 \pm 50 \mathrm{Ma}$

- Marincho Complex leucogranite: 2,067 $\pm 24 \mathrm{Ma}$

- leucogranite dykes cutting Marincho Complex: 1,969 \pm $25 \mathrm{Ma}$

2. The tectonic environment of emplacement of these rocks were determined as follows:

- syn-collisional environment for the Marincho Complex

- extensional environment for the Arroyo Grande Pluton

3. These data, suggest that there are three distinct periods of emplacement of granitoid rocks in the Precambrian of southern and central Uruguay as follows:

- Archean rocks. The massive alkaline granite blocks, dated at 2,544 Ma, prove that the greenschist facies metamorphism and associated deformation is older than this age.

- 2,290 - 2,180 Ma: Intrusion of small to medium-sized plutonic rocks, some of which are composite in nature. The older intrusions are calc-alkaline whereas the younger are alkaline. - 2,040 - 1,894 Ma: Intrusion of a number of small dykes which cross-cut the plutons formed at stage 2 .

Acknowledgements The authors wish to acknowledge the co-operation of DI.NA.MI.GE. in making possible the completion of this project. A grant from UQAM enabled the senior author to spend a year at UQAM working on this project. The NEWPET computer program of Daryl Clarke, Department of Earth Sciences, Memorial University of Newfoundland, greatly facilitated data analysis. Dr. Ron Doig, McGill University, Montreal, provided the program used to carry out the age calculations and helped enormously in the interpretation of the results. Careful reviews by two anonymous reviewers greatly improved the quality of the manuscript.

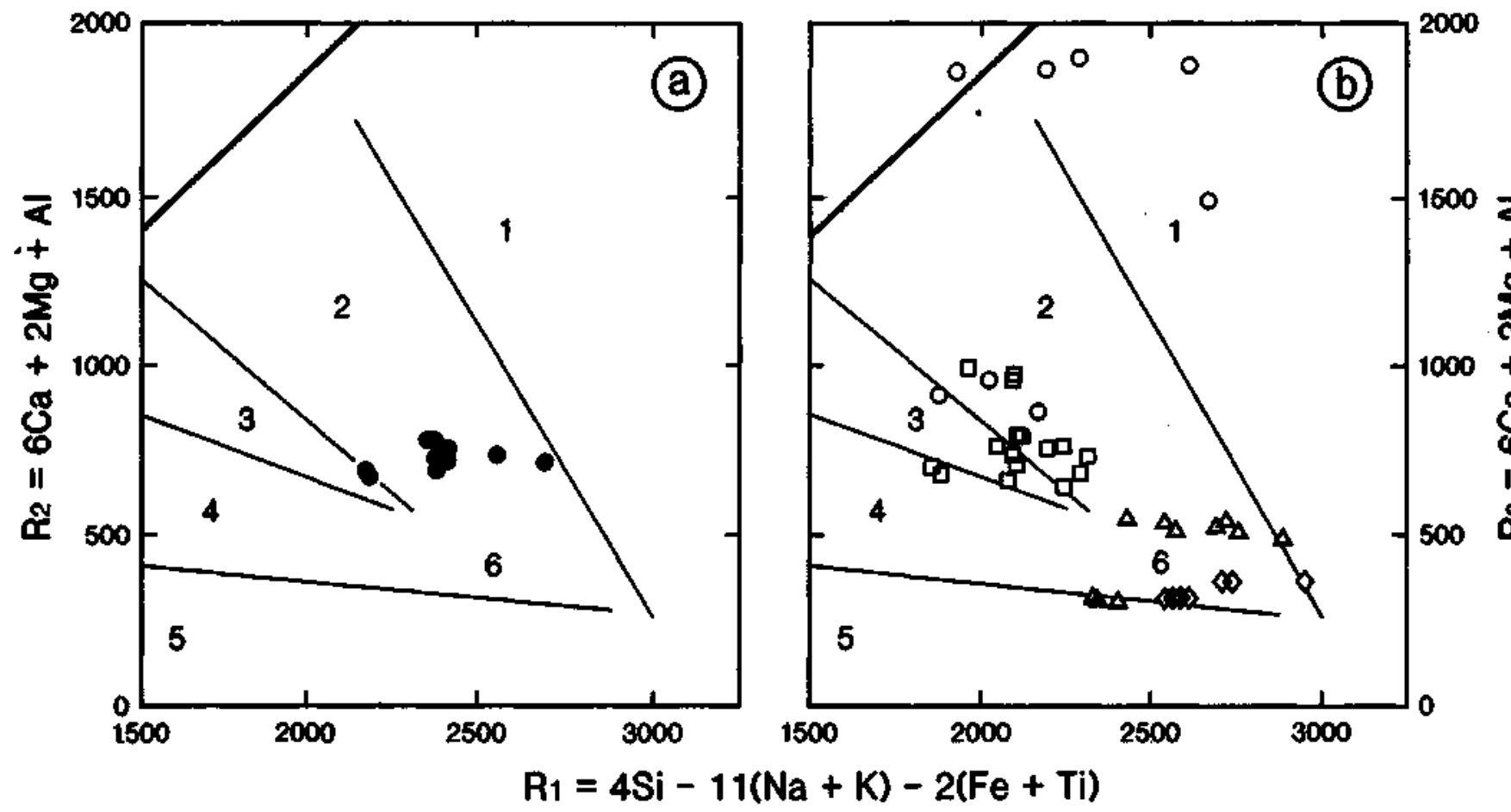

Figure 8 - Tectonic discriminant diagram for the AGP (8a) and the MC and SG (8b). After Batchelor \& Bowden (1985). Symbols as on figure 3

Figura 8 - Diagrama de discriminação tectônica para o AGP (8a) e o MC e SG (8b). A partir de Batchelor \& Bowden (1985). Simbologia como na figura 3 


\section{REFERENCES}

BATCHELOR, R. A. \& BOWDEN, P. 1985. Petrogenetic interpretation of granitoid rock series using multicationic parameters. Chem. GeoL 48:43-55.

BOSSI, J. 1983. Breve resefta sobre el conocimiento geológico des Escudo Predevoniano en Uruguay (Sud América). Zbl. Geol. Palaontol, $n^{\circ}: 417$ 429

CARD, K.D. 1990. A review of the Superior Province of the Canadian Shield, a product of Archean accretion. Precambrian. Res., 48:99-156.

DEBON, F. \& LeFORT, P. 1983. A chemical - mineralogical classification of common plutonic rocks and associations. Trans. R. Soc. Edinburgh.73:135-l49.

DEER, W.A.; HOWIE, R. A; ZUSSMAN, J., 1966. Rock-Forming Minerals. New York, Longmans. 371 p

EBADI, A. \& JOHANNES, W. 1991. Beginning of melting and composition of first melts in the system Qz-Ab-Or- $\mathrm{H}_{2} \mathrm{O}-\mathrm{CO}_{2}$. Contrib. Mineral. Petrol., 106:286-295.

FERNANDEZ AN \& PRECIOZZI, F 1974. La Formacion Arroyo Grande y losgranitoides asociados. In: CONOR. BRAS. GEOL, 28. Porto Alegre, 1974. Anais... Porto Alegre, SBG. p. 212-226.

FERRANDO, L. \& FERNANDEZ, A.N. 1971. Esquema tectónico estratigráfico del Predevoniano en el Uruguay. In: CONGR. BRAS. GEOL 25. São Paulo, 1971. Anais... São Paulo, SBG. p. 199-210.

IRVINE, T.N.\& BARAGAR, W.R.A. 1971. A guide to the chemical classification of the common volcanic rocks. Can. J. Earth Sci., 8:523-548

LaROCHE, H.; LETERRIER, J.; GRAN,DCLAUDE, P.; MARCHAL, M., 1980. A classification of volcanic and plutonic rocks using R1-R2 diagram and major element analyses. Its relationships with current nomenclature. Chem. GeoL, 29:183-210.

MANIAR,P.D.\& PICCOLI, PM. 1989. Tectonic discrimination of granitoids Geol. Soc. Am. Bull., 101:635-643.
PRECIOZZI, F. 1989. Mineralogia y Geoquimica del Complejo Intrusive de Arroyo Marincho y Granodiorita de Arroyo Grande. Montevideo, DI. N A MI. GE., Ministério de Industria, Energia y Minería del Uruguay. (Contribución Geologia de Uruguay 8).

PRECIOZZI, F. 1992. Aspectos Geocronológicos dei Terreno Piedra Alta: una Contribucion ai Estudio de la Geologia del Uruguay. Montevideo, DI. NA MI. GE., Ministério de Industria, Energia y Minería del Uruguay. (Unpublished Report).

PRECIOZZI, F. \& BOURNE, J.H. 1992. Petrography and geochemistry of the Arroyo de la Virgen and Isla Mala Plutons, southern Uruguay, with a comment on tectonic implications for the Transamazonian orogeny. J. South Am. Earth Sci.. 6:169-181.

PRECIOZZI, R. SPOTURNO, J. HEINZEN, W, 1979 . Carta Geo-Estructural del Uruguay, aEscala J: 2,000,000 yMemória Explicativa. Montevideo, DI. NA MI. GE., Ministério de Industria y Energia del Uruguay. 39 p.

PRECIOZZI, R; SPOTURNO, J.; HEINZEN, W.; ROSSI, P. 1985. Memória Explicativa de Ia Carta Geológica del Uruguay a Ia Escala J:500.000. Montevideo, DI.NAMI.GE., Ministério de Industria y Energia del Uruguay. $90 \mathrm{p}$.

WINKLER, H.G.F. 1979. Petrogenesis of the Metamorphic Rocks. 5 ed. New York, Springer Verlag. $348 \mathrm{p}$.

YORK, D. 1966. Least-squares fitting of a straight line. Can. J. Phys., 44:10791086.

MANUSCRITO A752

Recebido em 5 de fevereiro de 1993

Revisão do autor em 9 de agosto de 1994 Revisão aceita em 17 de agosto de 1994 